\title{
UKRAINIAN STATE REGIONAL DEVELOPMENT FUND: CURRENT REALITIES, OPPORTUNITIES AND PROSPECTS
}

\author{
MARIIA DANYLIUK, MARTA DMYTRYSHYN
}

\begin{abstract}
The article examines the modern realities of the functioning of the State Regional Development Fund as a budget program within the State Budget of Ukraine. The purpose of the study is to reveal the key features of the Fund functioning in modern conditions, to assess the current state of financial support of regional development projects, to identify the main problems in this field, and to develop possible solutions. The article substantiates the importance of sustainable development of territories as a mode of functioning of the region, characterized by harmonious positive changes in the most important spheres of life of the individual, society, and state, considering the interests of present and future generations. The change of the tendency of the gap between the declared and approved volumes of financing of regional development projects in 2015-2021 is estimated and the possible consequences of such gap are outlined. The volume and number of development projects in the regional and district dimension, funded by the Ukrainian State Regional Development Fund in 2020, are marked on the map of Ukraine. The need for uniform distribution of project financing based on the new zoning and elimination of "white spots" on the project map is emphasized. The ratio of the number of regional development projects in terms of settlements of implementation by their status was studied. Structural analysis of the use of funds of the Ukrainian State Regional Development Fund by purpose and type of work is performed; the average cost of regional development projects by category and in general are calculated and compared. Based on the analysis, the "bottlenecks" of the Ukrainian State Regional Development Fund functioning at the present stage are identified and the ways to solve them are proposed.
\end{abstract}

Keywords: State Regional Development Fund, regional development, sustainable development, regional development projects, regional development financing.

JEL Classification: G28, H72, O18. 


\section{INTRODUCTION}

In the context of decentralization sustainable development of regions is one of the priorities, as competitive regions are the basis for the growth of the whole country, the conducting of the reducing regional disparities national policy, promoting more balanced progress, creating conditions for improving the welfare of citizens.

Sustainable development of the region can be defined as a mode of functioning of the region, characterized by harmonious positive changes in the most important spheres of life of the individual, society and the state, taking into account the interests of present and future generations.

Sustainable development presupposes a humanistic orientation of stimulating the region's economy. It is assumed that the reproduction of socio-economic potential is balanced, the proportions between the components of the regional socio-economic system meet the standards. In such conditions, economic growth not only includes the growth of production and income but also involves progressive changes in the institutional, natural, environmental, social components of the regional system.

The driver of sustainable regional development is to ensure the working conditions of local authorities in its territory with a significant degree of autonomy, while accountable to the state and civil society. Similarly, they must have sufficient financial resources to develop the potential of the territory.

\section{THEORETICAL BACKGROUND}

Researchers from different countries pay attention to the regional development in their local areas. In particular, T. Talitha , T. Firman and D. Hudalah discovered decentralization in Indonesia [1]; J. Jia, G. Ma, C. Qin and L. Wang - place-based policies in China [2]; N. Matteucci - digital agendas, regional policy and institutional quality the Italian broadband plan [3]; N. Surubaru - the impact of European aid on national and local development in Bulgaria and Romania [4]; F. Silvestri, and F. Spigarelli and M. Tassinari analyzed regional development of circular economy in the European Union [5]. By this time, E. Merkaj, R. Lucchetti and F. Fiorillo underlined the role of local leaders in regional development funding [6], M. Klofsten, C. Norrman, E. Cadorin and H. Löfsten studied three regional initiatives of the support and development of small and new firms in rural areas [7]; N.Henry and A. Smith evaluated the post-brexit urban and regional development futures [8]; N. Moşteanu discovered green sustainable regional development and digital era [9]; K. Malik, L. Mach, M. Szewczuk-Stepien and P. Bebenek discussed specialization integrated strategy of innovations as an effective model for emerging regional economy development [10]; B. Asheim looked for the new path development in less innovative regions in smart specialization, innovation policy, and regional innovation systems [11]; M. Grillitsch and M. Sotarauta searched the trinity of change agency, regional development paths and opportunity spaces [12]. Finally, U. Andrusiv, L. Simkiv, O. Dovgal, N. Demchuk, N. Potryvaieva, A. Cherchata, I. Popadynets, G. Tkachenko, O. Serhieieva and $\mathrm{H}$. Sydor made an analysis of the economic development of Ukraine regions based on the taxonomy method [13]; Y. Uzun, and S. Koch compared the scenarios of Regional Development of Ukraine in the Context of Internal Stability Establishment [14]; M.Getzner, and S. Moroz studied the case for regional development and foreign direct investment in Ukraine [15]. All above-mentioned researches show that the chosen topic of investigation is of interest, on the world science agenda, puts many open questions and problems to be solved.

\section{Research Objective, Methodology and Data}

Researchers Modern literature review and local problems of regional development made us feel the need to investigate the current features of the Ukrainian State Regional Development Fund. For this purpose, we have generalized the official government data including the regulations made by responsible authorities, statistical information on budget expenditures. To get the results we made 
mathematical calculations of fraction, absolute and relative deviation, arithmetic mean simple formula. For a better demonstration of the results of our analysis, we created a map on which showed different levels of the state value of indicators. Some information was processed by charts or tables. To conclude the results and develop the improvement ideas and suggestions, we used methods of economic research and empiric cognition such as analysis and synthesis, scientific abstraction, induction and deduction, economic policy, historical and logical methods, graphic and cartographic methods, and system approach.

\section{RESULTS AND DISCUSSION}

The reform of local self-government and territorial organization of power in Ukraine based on decentralization, implemented since 2015, has created new opportunities for the development of territorial communities. Decentralization is designed to stimulate regional development through two different processes:

- increase the productivity and efficiency of the allocation of state resources at the local level;

- mobilization and use of additional resources at the national level, the source of which is in local communities and the private sector.

The state policy of decentralization in Ukraine is aimed at ensuring balanced development of regions and reducing the level of interregional differentiation in socio-economic indicators. Providing balanced socio-economic development of the regions involves the synchronization of the following areas of state regional policy:

- stimulating economic development based on the creation of new centers of economic growth in the regions, considering the unique competitive advantages of each territory and their specialization.

- coordination of infrastructural investments of the state and investment strategies of business in the regions considering development priorities and resource constraints.

- reduction of differentiation in the level and quality of life of the population in the regions through effective mechanisms of social and budgetary policy.

The instrument of financial support of the state policy of decentralization is the State Regional Development Fund, which was created to finance investment projects and programs that do not contradict the priorities defined in the State Strategy for Regional Development for 2021-2027 [16]. The creation of the Fund allows to move away from the practice of financing low-cost objects of the budget sphere from the state budget and to start financing regional development projects in Ukraine on a competitive basis, by development strategies and action plans for their implementation. And each project submitted for funding must pass a transparent competitive selection, prove its economic and social efficiency.

Projects are financed if they provide for:

- creation of an infrastructure of industrial and innovation parks.

- development of sports infrastructure.

- development of energy efficiency of state, communal, educational, medical institutions.

- support for voluntarily united territorial communities.

- cooperation projects of territorial communities [17, 18].

In general, the declared areas are in line with European practice. Thus, the European Regional Development Fund provides the allocation of funds to:

- innovation and research;

- the digital agenda;

- support for small and medium-sized enterprises;

- low-carbon economy.

In addition, the resources allocated by the fund for these priorities depend on the category of the region. In more developed regions, at least $80 \%$ of funds should focus on at least two of these priorities; 
In regions with transition economics, this focus is for $60 \%$ of the funds. For less developed regions the rate is $50 \%$. Low-carbon projects are also additionally funded [19].

In 2020, a new administrative-territorial system was approved [20, 21], which marked the completion of the creating of joint communities and the transition to an emphasis on their cooperation has started. However, the financial capacity of communities to self-sustain their development should also be considered, as no phenomenon or object in the economy and the state is static in the long run.

The Ukrainian State Regional Development Fund exists as part of the State Budget of Ukraine since 2012, but still has not acquired the status of a separate structure, consequently remains the target area of use of budget funds [22].

During the years of operation of such an initiative, in addition to the positive effect, many shortcomings in the system of regional development financing were also revealed. Thus, in 2019, the Accounting Chamber of Ukraine conducted a large-scale audit of the efficiency of the Fund's use. The report on this audit identified, in particular, a few issues [23]:

1) Measures to intensify local economic initiative, strengthen the productive potential of rural areas and other projects related to the expanded reproduction and promotion of employment were practically not financed. The main reasons for this were the lack of a unified regional policy on the regional development priorities.

2) Numerous facts of non-compliance with certain conditions by regional commissions and local state administrations for the selection of investment programs as well as regional development projects and the deadlines for their submission have been established in several regions.

3) Some projects selected by the regional commissions and included in the approved lists did not correspond to the regional development strategies or action plan for their implementation.

4) The vast majority of the projects were aimed at solving urgent social issues of the regions such as the reconstruction and overhaul of schools, kindergartens, hospitals, construction and reconstruction of water mains, etc.

5) There is a practice of inefficient management of the funds and the return of a significant part of them to the state budget (2016) as unused.

Paragraph 1 of Article 241. of the Budget Code of Ukraine stipulates that the State Regional Development Fund is determined to be at least 1 percent of the projected revenue of the general fund of the State Budget of Ukraine for the budget period. However, from 2015 to 2021 annually, this paragraph was suspended [24]. Thus, the key problem of the Ukrainian State Regional Development Fund is chronic underfunding.

The analysis of the declared and approved volumes of financing of the Ukrainian State Regional Development Fund is given in Tab. 1.

\begin{tabular}{|c|c|c|c|c|c|}
\hline Year & $\begin{array}{c}\text { Revenues of } \\
\text { the general } \\
\text { fund of the } \\
\text { State Budget } \\
\text { of Ukraine, } \\
\text { (1000 UAH) }\end{array}$ & $\begin{array}{c}\text { Declared } \\
\text { expenditures of } \\
\text { the Regional } \\
\text { Development } \\
\text { Fund, (1000 } \\
\text { UAH) }\end{array}$ & $\begin{array}{c}\text { Approved } \\
\text { expenditures of } \\
\text { the Regional } \\
\text { Development } \\
\text { Fund, (1000 } \\
\text { UAH) }\end{array}$ & $\begin{array}{c}\text { Absolute } \\
\text { expenditures of } \\
\text { the Regional } \\
\text { Development } \\
\text { Fund, \% }\end{array}$ & $\begin{array}{c}\text { deviation of the } \\
\text { planned } \\
\text { expenditures of } \\
\text { the Regional } \\
\text { Development } \\
\text { Fund from the } \\
\text { declared (1000 } \\
\text { UAH) }\end{array}$ \\
\hline $\mathbf{2 0 1 5}$ & 575613435.1 & 5756134.351 & 2900800 & $0.50 \%$ & -2855334.351 \\
\hline $\mathbf{2 0 1 6}$ & 575613435.1 & 5756134.351 & 3000000 & $0.52 \%$ & -2756134.351 \\
\hline $\mathbf{2 0 1 7}$ & 702024121.8 & 7020241.218 & 3500000 & $0.50 \%$ & -3520241.218 \\
\hline $\mathbf{2 0 1 8}$ & 842853634.3 & 8428536.343 & 6000000 & $0.71 \%$ & -2428536.343 \\
\hline $\mathbf{2 0 1 9}$ & 908391357.7 & 9083913.577 & 7170000 & $0.79 \%$ & -1913913.577 \\
\hline $\mathbf{2 0 2 0}$ & 858746187.8 & 8587461.878 & 4900000 & $0.57 \%$ & -3687461.878 \\
\hline
\end{tabular}




\begin{tabular}{|c|c|c|c|c|c|}
\hline Year & $\begin{array}{c}\text { Revenues of } \\
\text { the general } \\
\text { fund of the } \\
\text { State Budget } \\
\text { of Ukraine, } \\
\text { (1000 UAH) }\end{array}$ & $\begin{array}{c}\text { Declared } \\
\text { expenditures of } \\
\text { the Regional } \\
\text { Development } \\
\text { Fund, (1000 } \\
\text { UAH) }\end{array}$ & $\begin{array}{c}\text { Approved } \\
\text { expenditures of } \\
\text { the Regional } \\
\text { Development } \\
\text { Fund, (1000 } \\
\text { UAH) }\end{array}$ & $\begin{array}{c}\text { Share of declared } \\
\text { expenditures of } \\
\text { the Regional } \\
\text { Development } \\
\text { Fund, \% }\end{array}$ & $\begin{array}{c}\text { Absolute } \\
\text { deviation of the } \\
\text { planned } \\
\text { expenditures of } \\
\text { the Regional } \\
\text { Development } \\
\text { Fund from the } \\
\text { declared (1000 } \\
\text { UAH) }\end{array}$ \\
\hline 2021 & 959854312.4 & 9598543.124 & 4500000 & $0.47 \%$ & -5098543.124 \\
\hline
\end{tabular}

Tab. 1. Declared and approved expenditures of the Ukrainian State Regional Development Fund in $2015-2021$ [25-31]. *

* Source: calculated by the authors based on the Law of Ukraine "On the State Budget of Ukraine for the relevant year"

** Source: except for the temporarily occupied territories of the Autonomous Republic of Crimea and certain districts of Donetsk and Luhansk regions

According to Table 1, the actual amount of funding of the Regional Development Fund approved in the Laws of Ukraine "On the State Budget of Ukraine for the respective year" during 2015-2017 fluctuated around half of the amount of funding declared by the Budget Code of Ukraine. In 2018, the share of execution of declared expenditures on the fund increased, in 2019 it almost reached 4/5 of 1\% of the planned revenues of the general fund of the state budget. However, in 2020, the gap between declared and approved expenditures began to grow rapidly in favor of the latter. Accordingly, in the Law of Ukraine "On the State Budget for 2021" the amount of expenses on the regional development fund is only $0.47 \%$ of the revenues of the general fund of the state budget of the current year.

The tendency to gap between the declared and approved volumes of financing of regional development projects is well visible in Fig. 1.

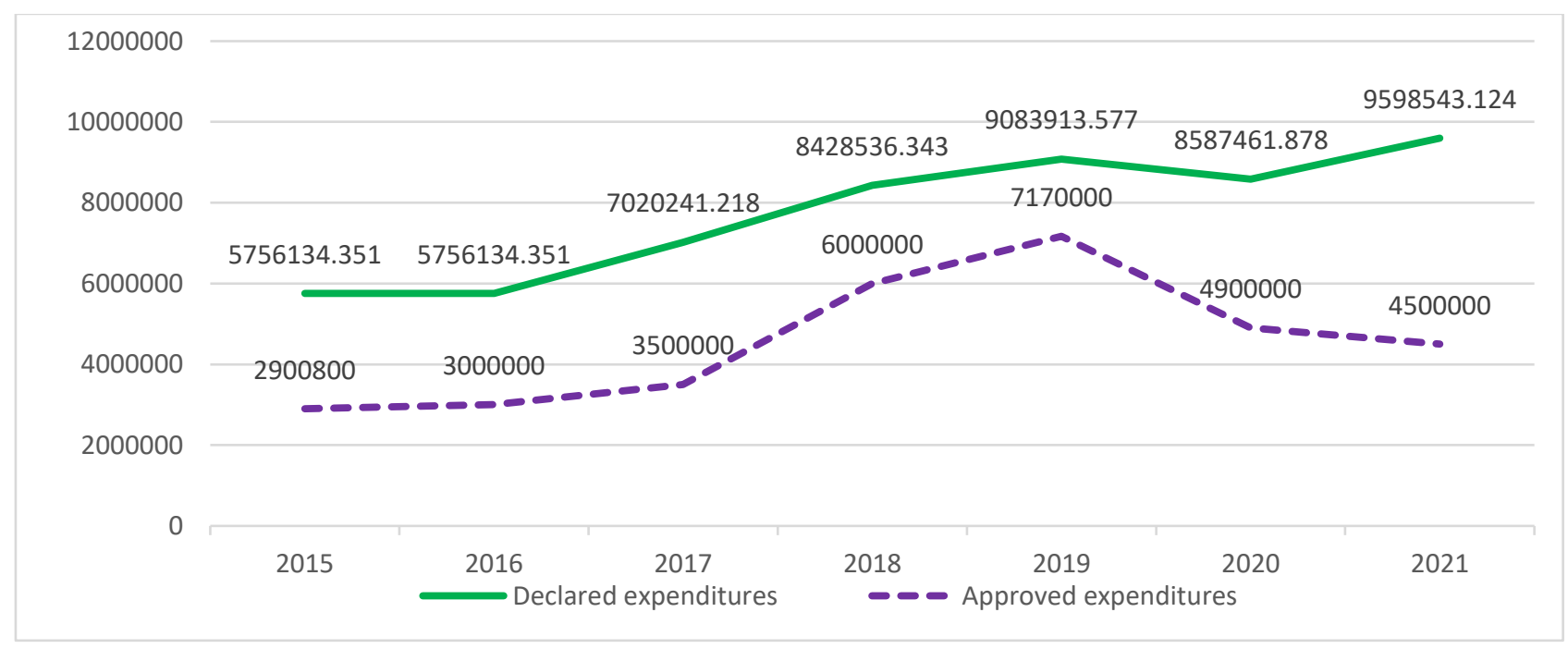

Fig. 1. Declared and approved by the Law of Ukraine "On the State Budget of Ukraine for the relevant year" (1000 UAH),

$$
\text { [25-31]. * }
$$

*Source: developed by the authors based on the Law of Ukraine "On the State Budget of Ukraine for the relevant year"

** Source: except for the temporarily occupied territories of the Autonomous Republic of Crimea and certain districts of Donetsk and Luhansk regions

In general, we consider this as a negative trend that may have a synergistic disincentive effect. Inflationary processes in our country cause an increase in prices for goods and services, which further reduces the useful effect of the implemented projects, otherwise, they require more funding at these 
prices. In addition, new modern, innovative, interactive technologies are emerging every year to promote education, maintain a healthy lifestyle, conserve energy, care for the environment and stimulate entrepreneurship, enabling Ukrainians to move from survival to growth. They objectively need additional attention as opposed to budget cuts.

The situation with the 2020 budget was explained by the former Prime Minister of Ukraine O. Honcharuk by the demand of the deputies to increase the subvention for the socio-economic development of the regions, despite the expense of the Regional Development Fund [32]. This subvention is also called "deputy", as it is targeted to "deputy's contribution" to improving the lives of voters in their constituency and is actively used by various political forces. At the same time, it does not create a competitive environment among project developers and, in our opinion, does not contribute to natural effective growth in general.

In September 2020, the Minister of Communities and Territories of Ukraine O. Chernyshov announced the preparation of draft amendments to the Budget Code of Ukraine, which provides, in particular, to increase the expenditures quota on regional development projects to $3 \%$ of the general budget and other changes. However, given the above data on the declared and approved amounts of funding for projects of the State Regional Development Fund, which were not funded even by the current rule, there are concerns that these changes will not remain declarative [33].

Next, we will analyze the latest data on the use of funds of the State Regional Development Fund in 2020. Here and further, we will use the official data of the State Treasury of Ukraine for the construction of drawings, building tables, and carrying out calculations.

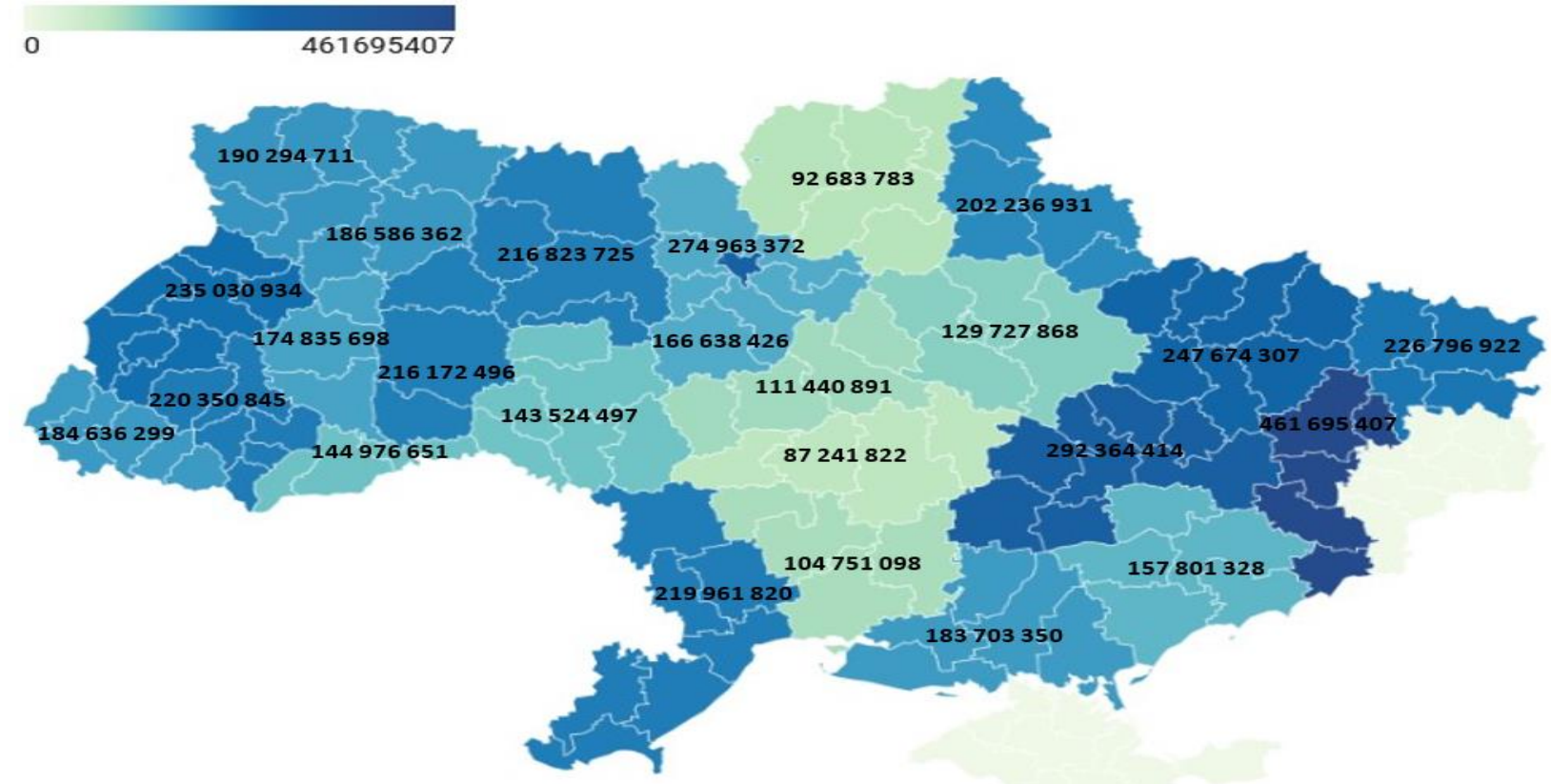

Fig. 2. The regional dimension of project financing by the Ukrainian State Regional Development Fund in 2020, UAH.*

* Source: formed by the authors based on data from the State Treasury of Ukraine [34] using the tool Datawrapper [35]

** Source: except for the temporarily occupied territories of the Autonomous Republic of Crimea and certain districts of Donetsk and Luhansk regions

Fig. 2 shows the shades of funding for regional development projects by the Ukrainian State Regional Development Fund in 2020. Accordingly, the darker the shade of the region, - the greater the amount of funding for the region. The lightest shade is marked by the temporarily occupied territories of Ukraine - the Autonomous Republic of Crimea and some districts of Donetsk and Luhansk regions, where there is no funding. 
In Fig. 2 we can see that the largest amount of funding for regional development projects in 2020 was for the Donetsk region, while in Kirovograd, Mykolaiv, and Chernihiv regions directed less more funding.

It should be noted that across the Kyiv region 16209104 UAH assignations were not distributed by the fund manager at the end of 2020.

Let's consider also the amount of funding for regional development projects in terms of areas of the new administrative-territorial system (Fig. 3).

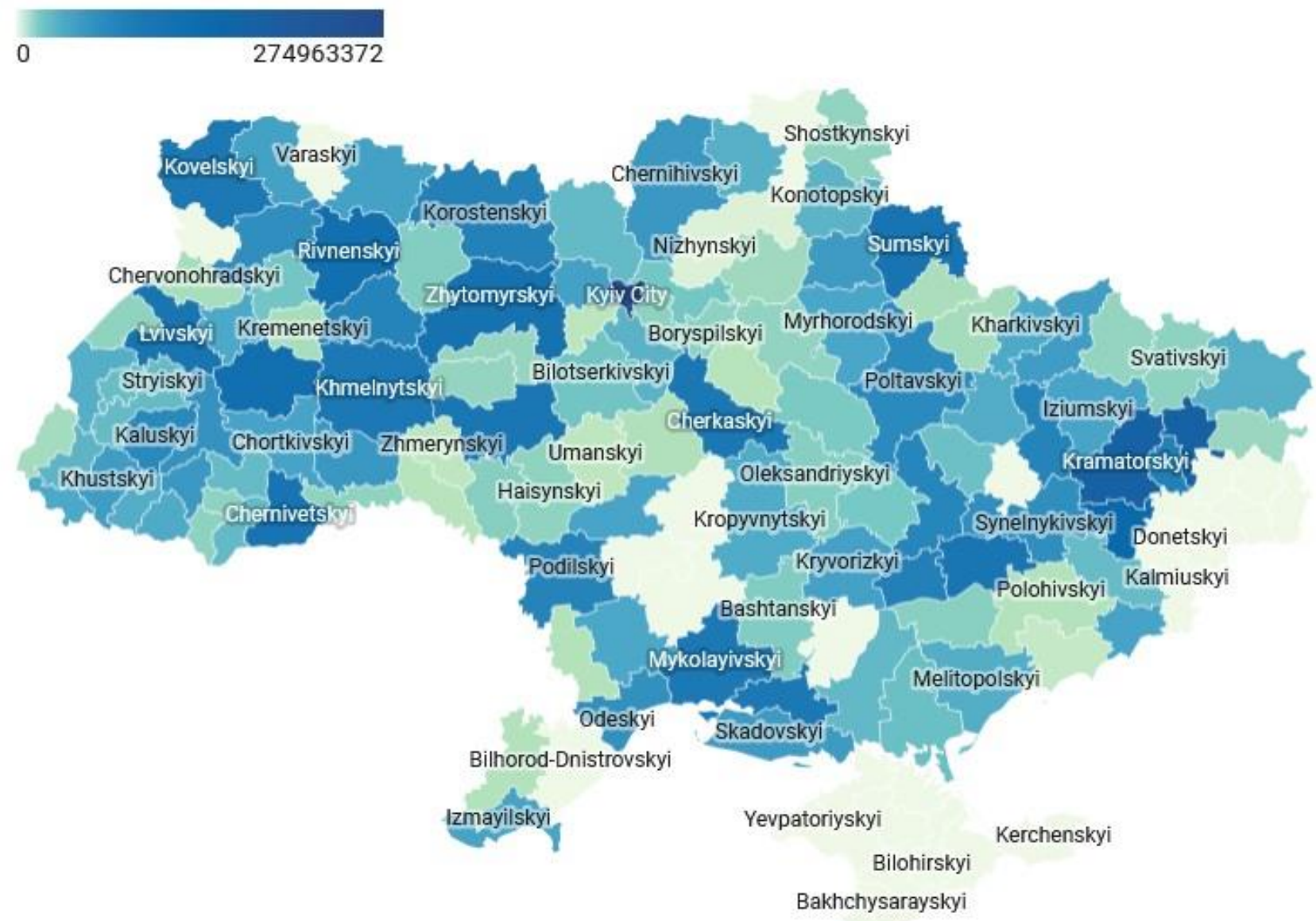

Fig. 3. District dimension of project financing by the Ukrainian State Regional Development Fund in 2020, UAH.*

* Source: formed by the authors based on from the State Treasury of Ukraine [34] using the tool Datawrapper [35]

** Source: except for the temporarily occupied territories of the Autonomous Republic of Crimea and certain districts of Donetsk and Luhansk regions

The map of Ukraine, presented in Fig. 3, shows the regions of Ukraine by the amount of funding for projects that were implemented in these areas in 2020. The renewed administrative-territorial structure of Ukraine also carried out the zoning of the temporarily occupied territories of our state, in particular, eleven districts were allocated within the Autonomous Republic of Crimea: Bakhchysarayskyi, Bilohirskyi, Dzhankoyskyi, Feodosiyskyi, Kerchenskyi, Kurmanskyi, Perekopskyi, Simferopolskyi, Yaltynskyi, Yevpatoriyskyi. Three districts of Donetsk region (Horlivskyi, Donetskyi, and Kalmiuskyi) and four districts of Luhansk region (Alchevskyi, Dovzhanskyi, Luhanskyi, and Rovenkivskyi) in 2020 were also under temporary occupation. Thus, Ukraine did not fund regional development projects in the mentioned territories.

In addition, in the process of building a database on the financing of regional development projects in Ukraine in 2020, we found that some areas of other regions of Ukraine did not have implemented projects. These include, in particular: 
- Volodymyr-Volynskyi district of Volyn region.

- Pavlohradskyi district of Dnipropetrovsk region.

- Novoukrainskyi district of Kirovohrad region.

- Voznesenskyi and Pervomaiskyi districts of the Mykolaiv region.

- Bilhorod-Dnistrovskyi district of Odesa region.

- Varaskyi district of Rivne region.

- Beryslavskyi district of Kherson region.

- Novhorod-Siverskyi district of Chernihiv region.

Thus, nine districts in eight regions of Ukraine did not implement projects at the expense of the Ukrainian State Regional Development Fund in 2020.

The record holders in terms of funding for regional development projects in 2020 were:

- Zhytomyrskyi district of Zhytomyr region.

- Zaporizkyi district of Zaporizhia region.

- Ternopilskyi district of Ternopil region.

- Sumskyi district of Sumy region.

- Rivnenskyi district of Rivne region.

- Lvivskyi district of Lviv region.

- Chernivetskyi district of Chernivtsi region.

- Sievierodonetskyi district of Luhansk region.

- Kramatorskyi and Pokrovskyi districts of Donetsk region.

All the above-mentioned districts financed the projects of the regional region in the district for over UAH 100 million. In addition, five large projects implemented in Kyiv cost the budget a total of almost 275 million UAH.

Next, we will conduct a similar analysis of the number of implemented regional development projects in the regional (Fig. 4) and district (Fig. 5) dimension.

In terms of regions in 2020, most projects were implemented in such areas as:

- $\quad$ Ternopil region - 34 projects.

- Donetsk region - 32 projects.

- Ivano-Frankivsk region - 31 projects.

- Vinnytsia region - 30 projects.

Instead, the fewest regional development projects in 2020 were implemented in:

- Kirovohrad region - 9 projects.

- Mykolaiv region - 4 projects.

If we examine the map of the number of implemented regional development projects in terms of districts (Fig. 4), we will see that most projects were implemented in:

- Ternopilskyi district of Ternopil region - 19 projects.

- Vinnytskyi district of Vinnytsia region - 16 projects.

- Sievierodonetskyi district of Luhansk region - 14 projects.

- Zhytomyrskyi district of Zhytomyr region - 13 projects.

- Kramatorskyi district of Donetsk region - 12 projects.

- Sumskyi district of Sumy region - 12 projects.

- Khersonskyi district of Kherson region - 11 projects.

In addition to the previously listed districts that did not have any regional development projects that could be implemented at the expense of the Ukrainian State Regional Development Fund, many districts have implemented 1-2 projects. Some projects with the same focus were implemented at several community objects according to a defined program. 
0 34

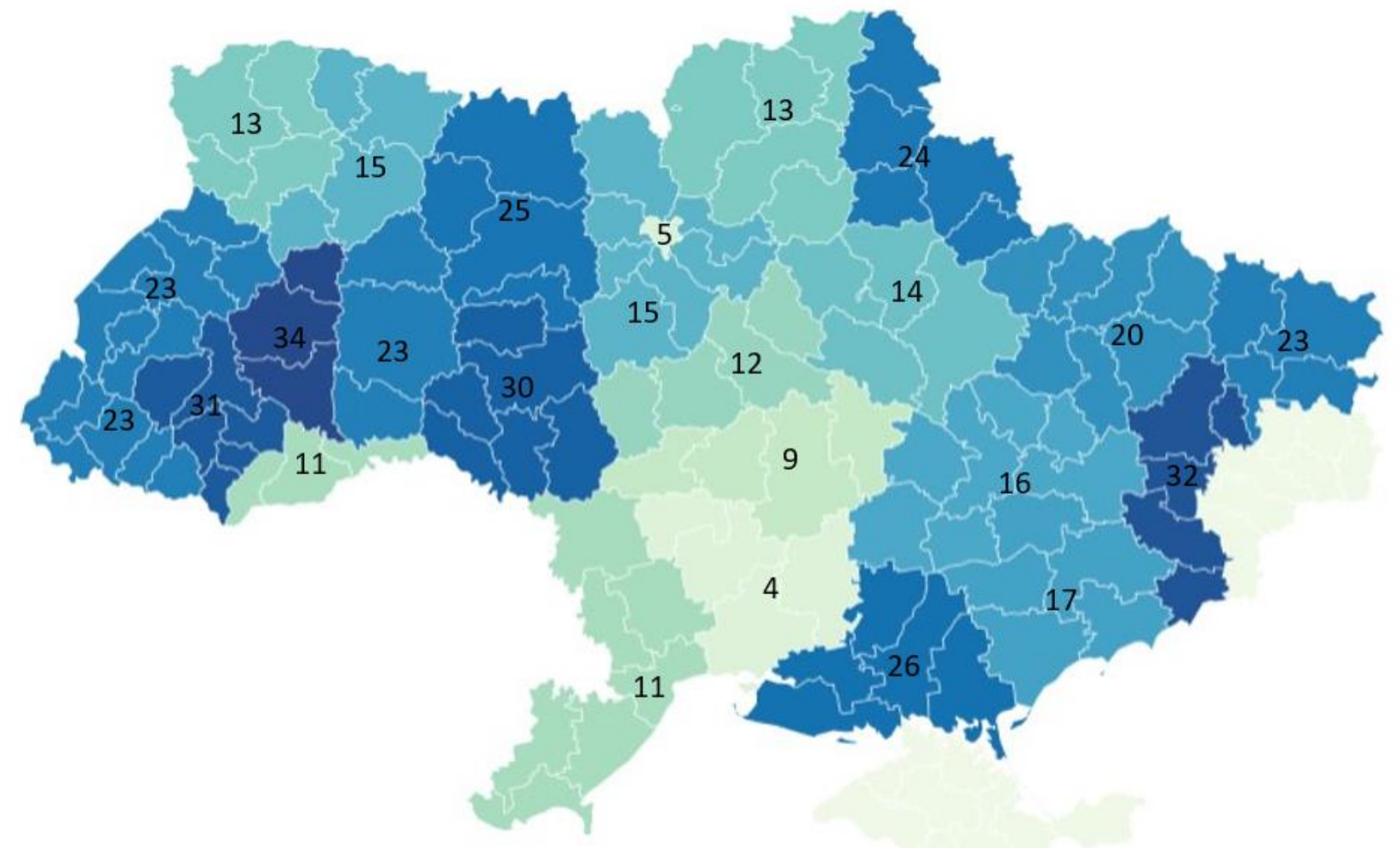

Fig. 4. Regional measurement of the number of projects implemented at the expense of the Ukrainian State Regional Development Fund in 2020, units. *

* Source: formed by the authors based on data from the State Treasury of Ukraine [34] using the tool Datawrapper [35]

** Source: except for the temporarily occupied territories of the Autonomous Republic of Crimea and certain districts of Donetsk and Luhansk regions

In total, 469 projects were implemented in different united territorial communities during the year, located territorially in villages, settlements, and cities (including district and regional centers). In this context, it should be noted that changes to the administrative-territorial structure of Ukraine were introduced in 2020, so such disparities in the development of districts can be considered accidental. However, regional commissions for the selection of competitive projects in the future should pay attention to the district dimension to avoid deepening differences in the development of territories.

The analysis also revealed a tendency to centralize projects in regional and district centers as opposed to their small proportional distribution in remote villages (Fig. 6).

It should also be noted that the center of the Autonomous Republic of Crimea and the regional centers of Donetsk (Donetsk) and Luhansk (Luhansk) regions are in the zone of temporary occupation of the territory of Ukraine.

Summarizing the above, we can sing out several regional centers that have implemented the maximum number of regional development projects. Among them, in particular, are:

- Vinnytsia - 10 projects or $33.3 \%$ of the regional number.

- Cherkasy - 7 projects or $58.3 \%$ of the regional number.

- Zaporizhia - 7 projects or $41.2 \%$ of the regional number.

- Ternopil - 7 projects or $20.6 \%$ of the regional number.

- Sumy - 6 projects or $25 \%$ of the regional number. 


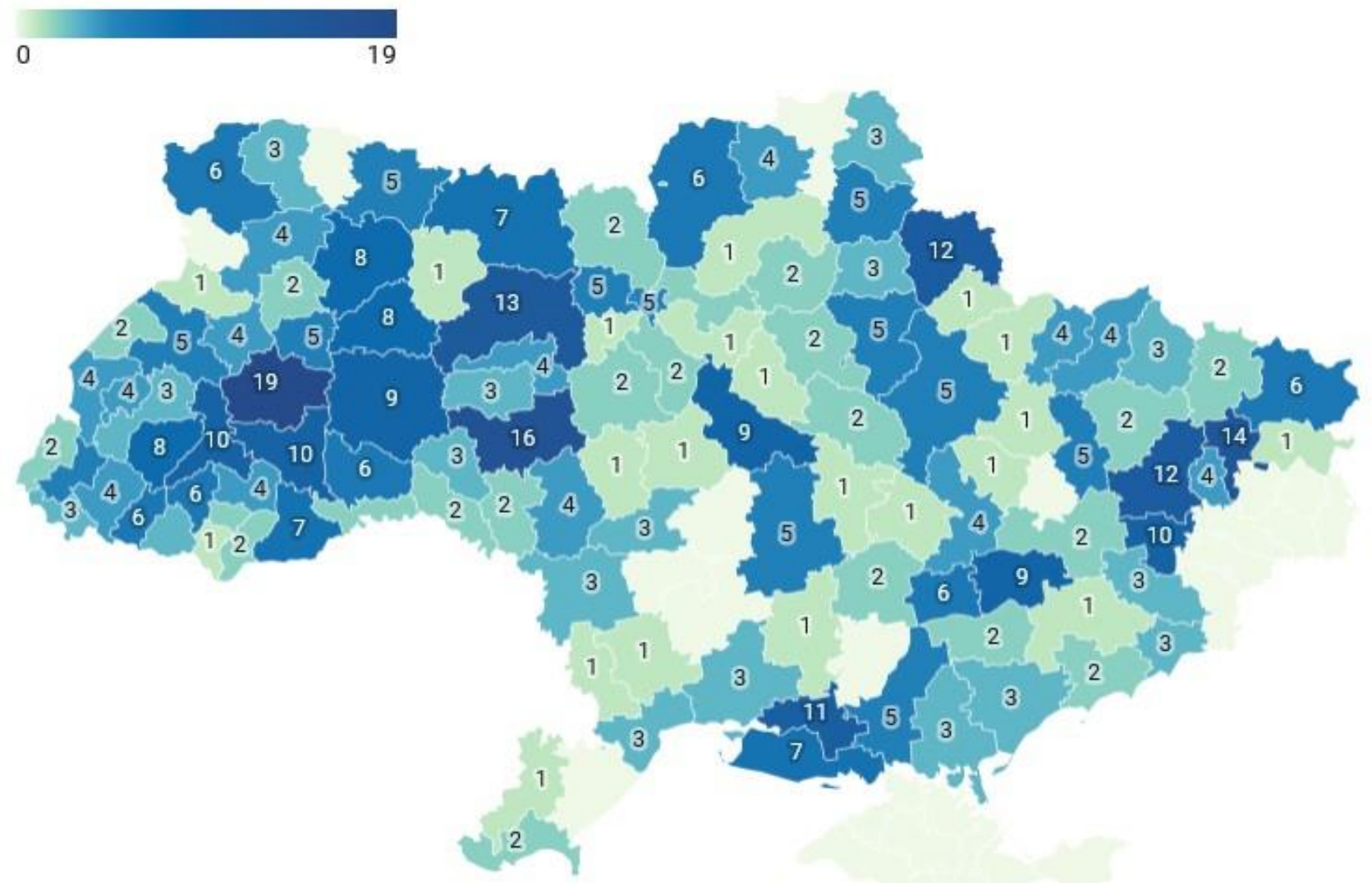

Fig. 5. District measurement of the number of projects implemented at the expense of the Ukrainian State Regional Development Fund in 2020, units. *

* Source: formed by the authors based on data from the State Treasury of Ukraine [34] using the tool Datawrapper [35]

** Source: except for the temporarily occupied territories of the Autonomous Republic of Crimea and certain districts of Donetsk and Luhansk regions

At the same time, Zakarpattia and Odesa regions did not implement projects in 2020 in their regional centers.

An important factor in the integrated development of regions by the state is the equable distribution of funds between territories and local budgets. Projects funded by the Ukrainian State Regional Development Fund must comply with the principle of uniformity, which is the pursuit of harmonious local development. After all, in modern conditions, one of the main challenges of financial and the economic activity of the state is to ensure the maximum possible balanced economic and social development of the regions, smoothing the existing disparities.

Let's further investigate the purpose of regional development projects by areas of funding (Tab. 2). 


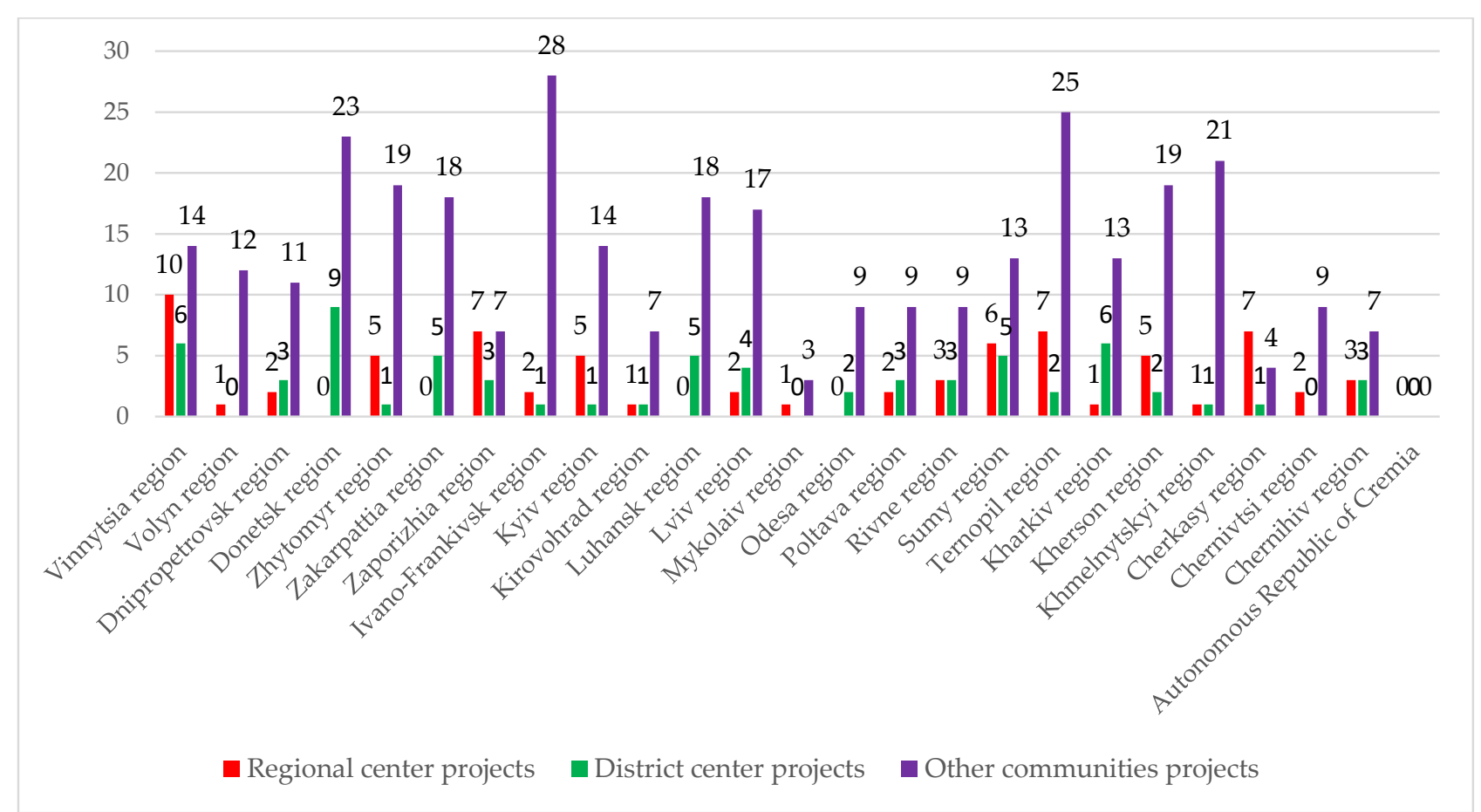

Fig. 6. The ratio of the number of regional development projects implemented in regional centers, district centers (which are not regional), and other communities at the expense of the State Fund for Regional Development of Ukraine in 2020, units *.

* Source: developed by the authors based on data from the State Treasury of Ukraine [34]

** Source: except for the temporarily occupied territories of the Autonomous Republic of Crimea and certain districts of Donetsk and Luhansk regions

\begin{tabular}{|c|c|c|c|c|c|}
\hline Sphere & $\begin{array}{c}\text { Financing } \\
\text { sum, UAH }\end{array}$ & $\begin{array}{c}\text { Project } \\
\text { quantity, } \\
\text { units }\end{array}$ & $\begin{array}{c}\text { Financing } \\
\text { quota, \% }\end{array}$ & $\begin{array}{c}\text { Quantity } \\
\text { quota, \% }\end{array}$ & $\begin{array}{c}\text { The average cost of } \\
\text { the project by } \\
\text { category, UAH }\end{array}$ \\
\hline Education & 2613904.0 & 255 & $53.82 \%$ & $54.37 \%$ & 10250.6 \\
\hline Health & 583163.9 & 53 & $12.01 \%$ & $11.30 \%$ & 11004.1 \\
\hline Culture and leisure & 172204.2 & 28 & $3.55 \%$ & $5.97 \%$ & 6150.2 \\
\hline Sport & 774128.8 & 82 & $15.94 \%$ & $17.48 \%$ & 9440.6 \\
\hline Utilities & 288770.5 & 16 & $5.95 \%$ & $3.41 \%$ & 18048.2 \\
\hline $\begin{array}{c}\text { Administrative and } \\
\text { social services }\end{array}$ & 180820.5 & 18 & $3.72 \%$ & $3.84 \%$ & 10045.6 \\
\hline $\begin{array}{c}\text { Roads and } \\
\text { infrastructure }\end{array}$ & 243712.9 & 17 & $5.02 \%$ & $3.62 \%$ & 14336.1 \\
\hline Total & $\mathbf{4 8 5 6 7 0 4 . 9}$ & $\mathbf{4 6 9}$ & $\mathbf{1 0 0 . 0 0 \%}$ & $\mathbf{1 0 0 . 0 0 \%}$ & $\mathbf{1 0 3 5 5 . 4 1}$ \\
\hline
\end{tabular}

Tab. 2. Analysis of the use of funds of the Ukrainian State Regional Development Fund in 2020 by purpose, 1000 UAH.*

* Source: developed by the authors based on data from the State Treasury of Ukraine [34]

** Source: except for the temporarily occupied territories of the Autonomous Republic of Crimea and certain districts of Donetsk and Luhansk regions

*** Source: UAH 16,209,104 of funding for the Kyiv region has not been distributed by the end of 2020

For a better illustration, we present the data obtained as a result of the analysis in the form of figures (Fig. 7-9). 

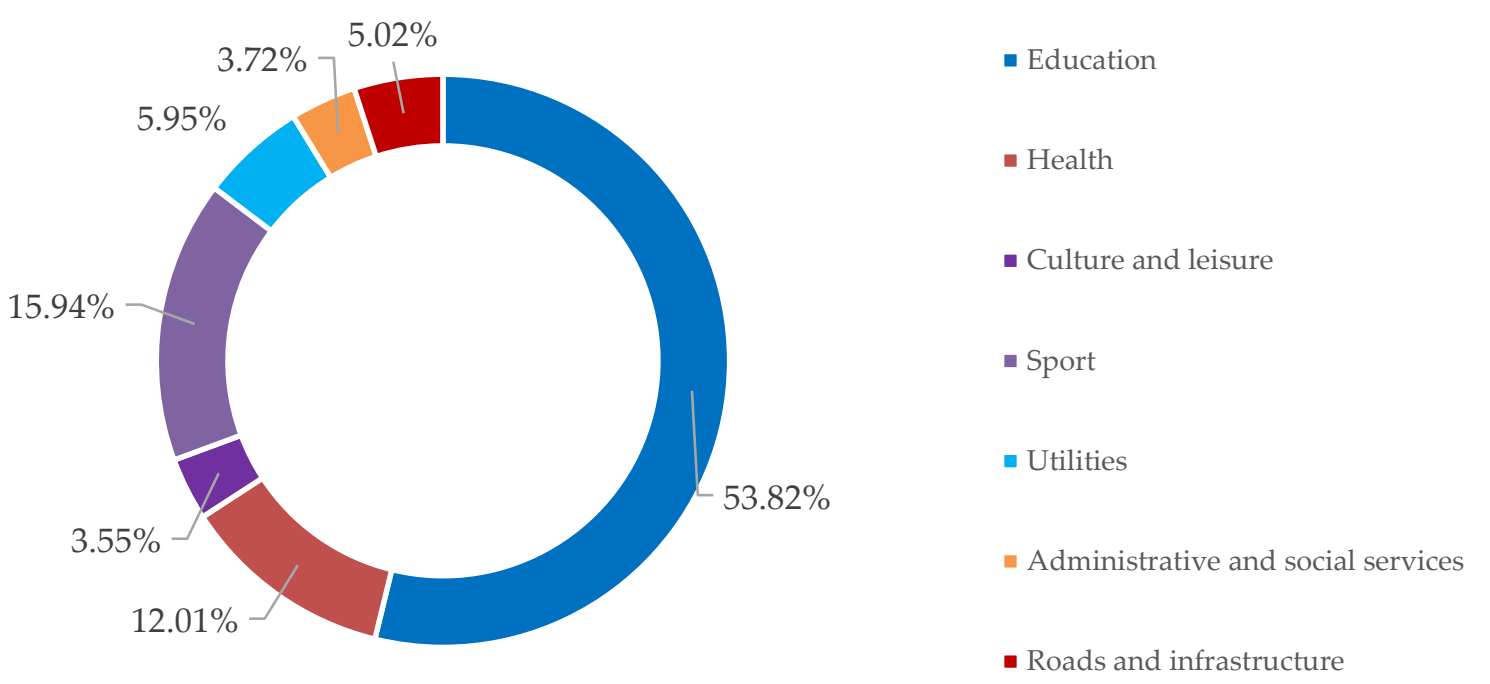

Fig. 7. Quota of financing of projects of the Ukrainian State Regional Development Fund in 2020 by purpose, \%

* Source: developed by the authors based on data from the State Treasury of Ukraine [34] and calculations of Tab. 2.

** Source: except for the temporarily occupied territories of the Autonomous Republic of Crimea and certain districts of Donetsk and Luhansk regions

Thus, the pie charts in Figures 7 and 8 show the share of regional development projects that were financed by the Ukrainian State Regional Development Fund in 2020 in the amount and quantity, respectively.
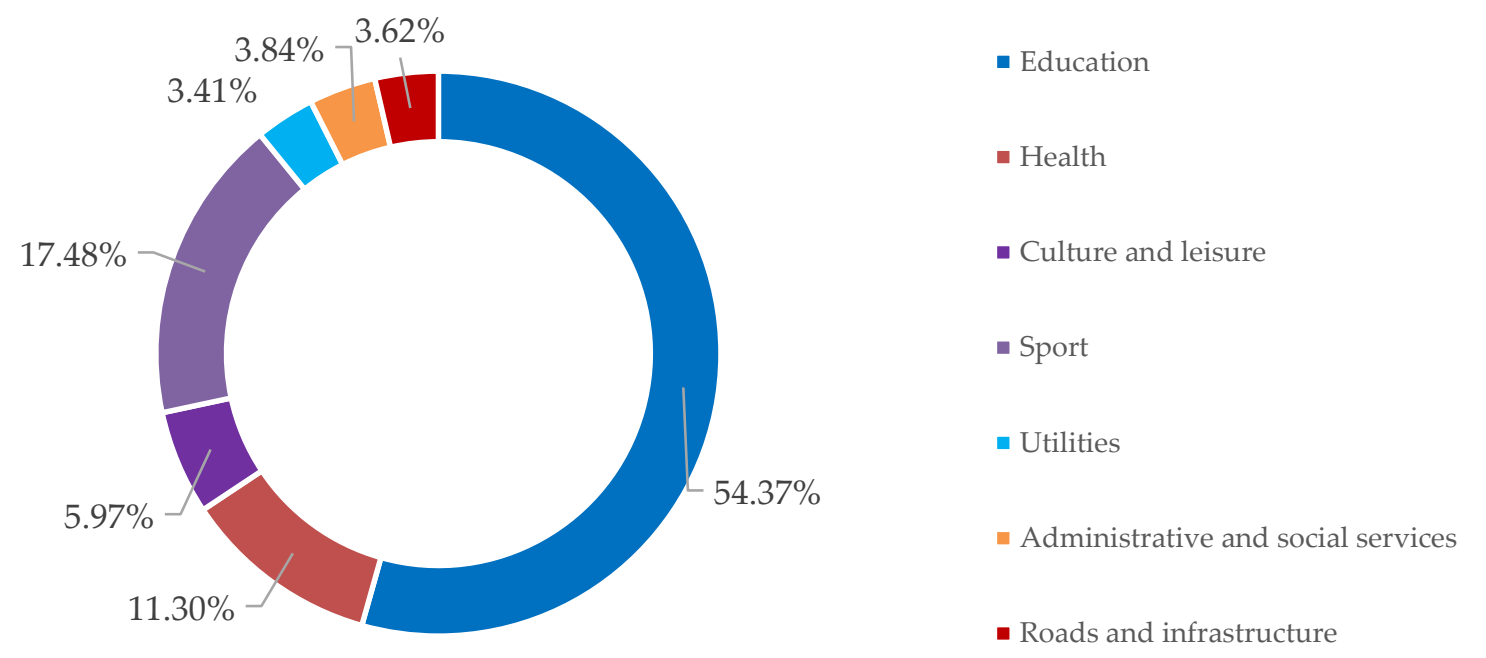

Fig. 8. Quota of financing of projects of the Ukrainian State Regional Development Fund in 2020 by category, \%

* Source: developed by the authors based on data from the State Treasury of Ukraine [34] and calculations of Tab. 2.

** Source: except for the temporarily occupied territories of the Autonomous Republic of Crimea and certain districts of Donetsk and Luhansk regions

In fig. 9 columns show the average cost of a regional development project by areas of implementation, and the graph shows the total average cost. Thus, it can be seen that although more than half of all funding was directed to educational projects, their average cost is much lower than the overall average for the fund. At the same time, health, utilities, roads, and infrastructure projects were rare and expensive. All other funded areas, such as culture and leisure, sports, administrative and 
social services, are also characterized by the average cost of the project by categories smaller than the overall average.

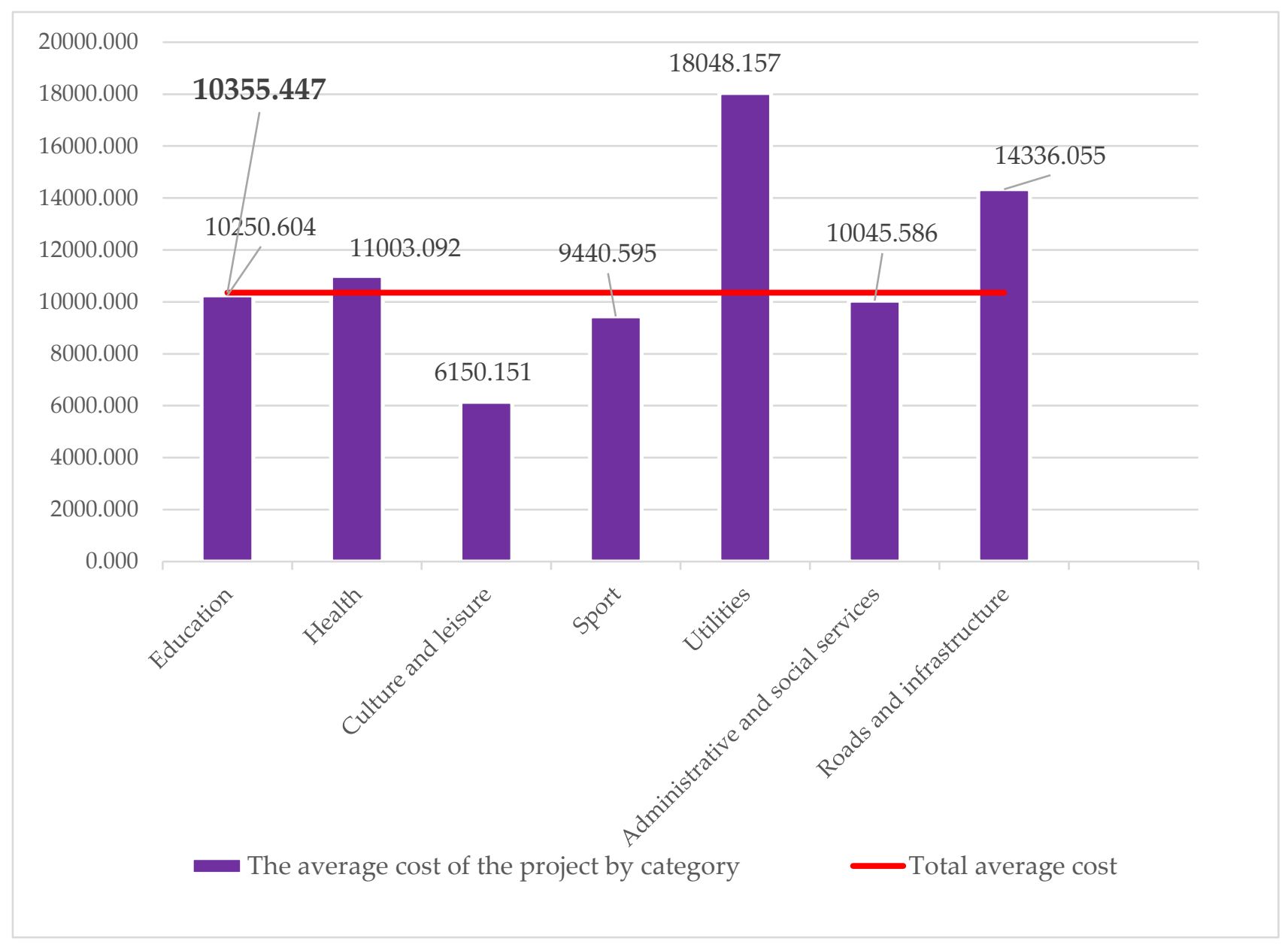

Fig. 9. Average cost of the implemented project of the Ukrainian State Regional Development Fund by categories and total in 2020, 1000 UAH.

* Source: developed by the authors based on data from the State Treasury of Ukraine [34] and calculations of Tab. 2.

** Source: except for the temporarily occupied territories of the Autonomous Republic of Crimea and certain districts of Donetsk and Luhansk regions

According to the analysis, we can see that more than half of the expenditures of the Ukrainian State Regional Development Fund in 2020 were directed to the financing of education. Mostly these are projects of repair, reconstruction, and construction of schools and kindergartens as a whole or their separate parts.

Most of the fund's health expenditures are similar; only some projects are aimed at installing new modern equipment.

Likewise, a significant part of funds for regional development projects was directed to the development of sports infrastructure. This is the construction of stadiums, swimming pools, and sports complexes in general.

The category of culture and leisure includes projects for the construction and reconstruction of cultural centers, museums, as well as parks and squares for recreation.

Utility projects focused mainly on the reconstruction or repair of water mains and sewage systems.

In the category "Administrative and social services" are presented, in particular, projects to create centers for the provision of administrative services, as well as services for socially disadvantaged groups.

The category of road infrastructure includes mostly repair, reconstruction, and construction of roads, bridges, transport interchanges. 
Considering the analysis presented in Table 1, we can see that the least evaluated in the field of culture and sports. It can be assumed that in the conditions of very worn-out road infrastructure, leaky roofs of hospitals, unacceptable condition of schools, cultural objects are not of paramount importance. However, in our opinion, this is very dangerous in the conditions of hybrid information warfare and aggressive propaganda. After all, people that do not understand who they are, do not remember their traditions, language, and culture cannot break away from the values of survival and switch to the values of self-development, a priori.

By analogy, we will analyze the use of funds of the Ukrainian State Regional Development Fund in 2020 by the nature of the work performed (Tab. 3).

\begin{tabular}{|c|c|c|c|c|c|}
\hline $\begin{array}{c}\text { The nature of the use of } \\
\text { funds }\end{array}$ & $\begin{array}{c}\text { Financing } \\
\text { sum, UAH }\end{array}$ & $\begin{array}{c}\text { Project } \\
\text { quantity, } \\
\text { units }\end{array}$ & $\begin{array}{c}\text { Financing } \\
\text { quota, \% }\end{array}$ & $\begin{array}{c}\text { Quantity } \\
\text { quota, \% }\end{array}$ & $\begin{array}{c}\text { The average cost of } \\
\text { the project by } \\
\text { category, UAH }\end{array}$ \\
\hline Overhaul & 912881.5 & 111 & $18.80 \%$ & $23.67 \%$ & 8224.3 \\
\hline Reconstruction & 1916275.9 & 197 & $39.46 \%$ & $42.00 \%$ & 9727.3 \\
\hline Restoration & 17505.6 & 5 & $0.36 \%$ & $1.07 \%$ & 3501.1 \\
\hline Construction & 1633476 & 123 & $33.63 \%$ & $26.23 \%$ & 13280.3 \\
\hline $\begin{array}{c}\text { Other (repair and } \\
\text { completion, } \\
\text { reconstruction and } \\
\text { construction, acquisition, } \\
\text { arrangement, etc.) }\end{array}$ & 376566.2 & 33 & $7.75 \%$ & $7.04 \%$ & 11411.1 \\
\hline Total & 4856704.9 & 469 & $100.00 \%$ & $100.00 \%$ & 10355.45 \\
\hline
\end{tabular}

Tab. 3. Analysis of the use of funds of the Ukrainian State Regional Development Fund in 2020

by the nature of work performed, $1000 \mathrm{UAH}$ * $^{*}$

* Source: developed by the authors based on data from the State Treasury of Ukraine [34]

** Source: except for the temporarily occupied territories of the Autonomous Republic of Crimea and certain districts of Donetsk and Luhansk regions

*** Source: UAH 16,209,104 of funding for the Kyiv region has not been distributed by the end of 2020

Table 2 shows that in 2020, a third part of the funding went to the construction of new facilities. In every need, new construction is more energy-efficient, modern, convenient, and relevant to current realities. However, if we pay attention to the average amount of funding for one construction project, UAH 13 million. generally is a scrimpy amount to create a new object. In addition, construction is usually a lengthy process that is difficult to complete in one reporting year. Thus, such projects risk becoming unfinished long-term construction in the conditions of unstable conditions and policy of the coming years.

In our opinion, in $\mathrm{f}$ projects financing the preference should be given to the unfinished construction of budget facilities (schools, kindergartens, hospitals) started with the involvement of state capital investments and other sources of funding, and which were stopped for various reasons, but at these facilities large volumes of construction and installation work, equipment was partially installed, and customers incurred costs for design, preparation of the construction site, and other capital costs. After all, such facilities have spent a significant number of budgetary resources, and they gradually lose their physical characteristics and become unusable under the influence of the environment.

During the analysis, we found that many projects cannot be clearly assigned to one category, because they involve, for instance, repair or reconstruction with the completion of the premises. Such projects were categorized as others.

The smallest quota of regional development projects is restoration. This category includes restoration and reconstruction projects that are monuments of history and architecture. Such projects require the involvement of narrow experts, historians, architects, sculptors. These professionals must preserve the historic appearance of the building under restoration as much as possible, and at the same 
time make it convenient for modern use. In our opinion, this direction is largely underestimated, as it represents a contribution not only to the educational and cultural development of Ukrainians, but also improves the tourist and investment attractiveness of the settlements in which it is implemented.

Whereas according to the definition, the Ukrainian State Regional Development Fund should finance development-oriented projects, additional attention was paid to the selection of those projects that have an innovative component or are aimed at modernization and energy saving.

Thus, we have identified only 9 projects that offer a certain innovative way to solve a problem or the installation of modern innovative equipment. These projects were implemented in six regions of Ukraine for a total of 101,211.8 thousand UAH. Only Lviv and Khmelnytsky regions implemented more than one innovation project ( 2 and 3 projects respectively). The rest of the regions, in our opinion, did not clearly fund innovative projects in 2020.

There were significantly more projects aimed at energy saving or thermal insulation - 72 projects totaling over 625 million UAH. Dnipropetrovsk, Kirovohrad, Odesa and Rivne regions did not implement energy saving projects in 2020. We assume that other modernization projects, among others, could have an innovative component or certain features of energy saving, but this was not clearly emphasized in the project description (therefore, it was not the key goal of their implementation).

Summarizing the above, we can conclude that the funds of the Ukrainian State Regional Development Fund were used to a greater extent to ensure the current activities of budgetary institutions, the so-called "patching holes" in chronic underfunding of Ukraine for decades. Definitely, if priority needs are not met, it is difficult to move on to development. Therefore, we consider such financing of the past periods to be logical and acceptable, but not strategic. If the state seeks to achieve real development of the regions, improve the standard and living conditions of Ukrainians (regardless of the place of residence), as well as create conditions for the spread of effective entrepreneurship and accumulation of human capital, development projects should not contain ideas of current life.

\section{CONCLUSIONS}

Thus, the Ukrainian State Regional Development Fund is a tool for competitive fundraising to finance development projects in the regions. Substantiation of the idea, preparation of the project application is a process that, on the one hand, requires effort, time, responsibility; on the other hand, it will contribute to the growth of professional, creative. and intellectual potential of Ukrainians in general. The reason is that any innovation requires concern, activity, production of new ideas. In addition, such a mechanism helps to reduce the corruption and lobbying components of the use of budget funds.

Improving the system of financing regional development from the budget, in our opinion, should include:

- clear and non-alternative nature of the innovative orientation of projects accepted for funding;

- quoting of small and medium business development projects;

- restriction of social projects in terms of their focus on creating an investment basis for further growth of both human and entrepreneurial capital in the regions;

- wider involvement of the population of communities in the discussion of projects at the stage of their preparation (including through strengthening publicity and public awareness);

- avoidance of corruption and lobbying influence of officials on the distribution of state budget funds through the transition to "manual control" of the process;

- uniform distribution of project financing based on the new zoning and elimination of "white spots" on the project map;

- optimization of project support to avoid unused amounts of funds for already approved projects;

- financing as a matter of priority for those facilities, the construction or reconstruction of which has already begun (to minimize the spread of long-term construction and construction in progress); 
- considering the need for counterpropaganda, strengthening the sense of national and cultural self-identification of Ukrainians to create islands of development in the controlled territory of Ukraine as opposed to uncontrolled.

The state and its citizens have many priority needs for urgent funding. In the conditions of limited resources. it is necessary to make a choice among alternatives. However, development projects are a tool that can stimulate further growth. This is the only way to achieve stable progress in the long run.

\section{REFERENCES}

[1] Talitha T., Firman T., Hudalah D. Welcoming two decades of decentralization in Indonesia: a regional development perspective. Territory, Politics, Governance, 8 (5) (2020), 690-708. doi: $10.1080 / 21622671.2019 .1601595$

[2] Jia J., Ma G., Qin C., Wang L. Place-based policies, state-led industrialisation, and regional development: Evidence from China's Great Western Development Programme. European Economic Review, 123 (103398) (2020), doi: 10.1016/j.euroecorev.2020.103398

[3] Matteucci N. Digital agendas, regional policy and institutional quality: assessing the Italian broadband plan. Regional Studies, 54 (9) (2020), 1304-1316. doi:10.1080/00343404.2020.1782876

[4] Surubaru N. C. European funds in Central and Eastern Europe: drivers of change or mere funding transfers? Evaluating the impact of European aid on national and local development in Bulgaria and Romania. European Politics and Society, 22 (2) (2021), 203-221. doi: 10.1080/23745118.2020.1729049

[5] Silvestri F., Spigarelli F., Tassinari M. Regional development of Circular Economy in the European Union: A multidimensional analysis. Journal of Cleaner Production, 255 (120218) (2020), doi: 10.1016/j.jclepro.2020.120218

[6] Merkaj E., Lucchetti R., Fiorillo, F. The role of local leaders in regional development funding: Evidence from an elite survey. Journal of Regional Science, 60 (4) (2020), 712-737. doi: 10.1111/jors.12482

[7] Klofsten M., Norrman, C., Cadorin, E., Löfsten, H. Support and development of small and new firms in rural areas: a case study of three regional initiatives. SN Applied Sciences, 2 (1) (2020), 1-9. doi: 10.1007/s42452-019-1908-z

[8] Henry N., Smith A. Europe and/or the UK: Post-Brexit urban and regional development futures - A special issue. European Urban and Regional Studies, 28 (1) (2021), 3-7. doi: 10.1177/0969776420982742

[9] Mosteanu N.R. Green Sustainable Regional Development and Digital Era. In: Sayigh A. (Eds.) Green Buildings and Renewable Energy. Innovative Renewable Energy, 181-197. doi: 10.1007/978-3-030-30841-4_13

[10] Malik K., Mach L., Szewczuk-Stepien M., Bebenek P. Specialization integrated strategy of innovations: effective model for emerging regional economy development? European Research Studies Journal, 23 (2) (2020), 78-97. Available at: https://www.um.edu.mt/library/oar/handle/123456789/57023

[11] Asheim B.T. Smart specialisation, innovation policy and regional innovation systems: what about new path development in less innovative regions? Innovation: The European Journal of Social Science Research, 32 (1) (2019), 8-25. doi: 10.1080/13511610.2018.1491001

[12] Grillitsch M., Sotarauta, M. Trinity of change agency, regional development paths and opportunity spaces. Progress in human geography, 44 (4) (2020), 704-723. doi:10.1177/0309132519853870

[13] Andrusiv U., Simkiv, L., Dovgal, O., Demchuk, N., Potryvaieva, N., Cherchata, A., Popadynets, I., Tkachenko, G., Serhieieva. O., Sydor, H. Analysis of economic development of Ukraine regions based on taxonomy method. Management Science Letters, 10 (3) (2020), 515-522. doi: 10.5267/j.msl.2019.9.029

[14] Uzun Y., Koch, S. Decentralization vs Centralization: Scenarios of Regional Development of Ukraine in the Context of Internal Stability Establishment. Przeglad Strategiczny, 13 (2020), 243-262. doi:10.14746/ps.2020.1.15

[15] Getzner M., Moroz, S. Regional development and foreign direct investment in transition countries: a case-study for regions in Ukraine. Post-Communist Economies, 32 (6) (2020), 813-832. doi: 10.1080/14631377.2020.1745564 
[16] Resolution of the Cabinet of Ministers of Ukraine "On approval of the State Strategy for Regional Development for 2021-2027". Available at: https://zakon.rada.gov.ua/laws/show/695-2020\%D0\%BF\#n676. (in Ukrainian)

[17] Decree of the President of Ukraine "On Sustainable Development Strategy "Ukraine - 2020" Available at: https://zakon.rada.gov.ua/laws/show/5/2015\#Text. (in Ukrainian)

[18] Resolution of the Cabinet of Ministers of Ukraine "Some issues of the state fund of regional development". Available at: https://zakon.rada.gov.ua/laws/show/196-2015-\%D0\%BF\#Text. (in Ukrainian)

[19] European Regional Development Fund. Available https://ec.europa.eu/regional_policy/en/funding/erdf/

[20] Law of Ukraine "On Amendments to Certain Laws of Ukraine Concerning the Definition of Territories and Administrative Centers of Territorial Communities". Available at: https://zakon.rada.gov.ua/laws/show/562-IX\#Text. (in Ukrainian)

[21] Resolution of the Verkhovna Rada of Ukraine. "On the formation and liquidation of districts". Available at: https://zakon.rada.gov.ua/laws/show/807-20\#Text (in Ukrainian).

[22] About the State Regional Development Fund. Available at: http://dfrr.minregion.gov.ua/pro-konkurs. (in Ukrainian)

[23] Report on the results of the audit of the effectiveness of the use of the state fund of regional development. Available at: https://rp.gov.ua/upload-files/Activity/Collegium/2019/7-1_2019/Zvit_71_2019.pdf. (in Ukrainian)

[24] Budget Code of Ukraine. Available at: https://zakon.rada.gov.ua/laws/show/2456-17\#Text (In Ukrainian).

[25] Verkhovna Rada of Ukraine. Law of Ukraine "On the State Budget of Ukraine for 2015". Available at: https://zakon.rada.gov.ua/laws/show/80-19\#Text. (in Ukrainian)

[26] Verkhovna Rada of Ukraine. Law of Ukraine "On the State Budget of Ukraine for 2016". Available at: https://zakon.rada.gov.ua/laws/show/928-19\#Text (in Ukrainian).

[27] Verkhovna Rada of Ukraine. Law of Ukraine "On the State Budget of Ukraine for 2017". Available at: https://zakon.rada.gov.ua/laws/show/1801-19\#Text.(in Ukrainian)

[28] Verkhovna Rada of Ukraine. Law of Ukraine "On the State Budget of Ukraine for 2018". Available at: https://zakon.rada.gov.ua/laws/show/2246-19\#Text. (In Ukrainian)

[29] Verkhovna Rada of Ukraine. Law of Ukraine "On the State Budget of Ukraine for 2019". Available at: https://zakon.rada.gov.ua/laws/show/2629-19\#Text. (in Ukrainian)

[30] Verkhovna Rada of Ukraine. Law of Ukraine "On the State Budget of Ukraine for 2020". Available at: https://zakon.rada.gov.ua/laws/show/1082-20\#Text. (in Ukrainian)

[31] Verkhovna Rada of Ukraine. Law of Ukraine "On the State Budget of Ukraine for 2021". Available at: https://zakon.rada.gov.ua/laws/show/1082-20\#Text. (in Ukrainian)

[32] The draft budget for 2020 returned to the second reading a subvention for socio-economic development, which is criticized by the Ministry of Finance. Available at: https://nv.ua/ukr/biz/finance/subvenciyu-na-socialno-ekonomichniy-rozvitok-povernuli-v-proektbyudzhetu-novini-ukrajini-50051665.html. (in Ukrainian)

[33] Chernyshov O. The reform of the State Regional Development Fund will allow for more efficient use of funds for regional development. Available at: https://www.kmu.gov.ua/news/oleksij-chernishovreforma-derzhavnogo-fondu-regionalnogo-rozvitku-dozvolit-efektivnishe-spryamovuvati-koshti-narozvitok-regioniv. (in Ukrainian)

[34] Information on the use of funds of the state regional development fund as of 01.01.2021. Available at: https://www.treasury.gov.ua/ua/kaznachejstvo-informuye/derzhavnij-fond-regionalnogo-rozvitku. (in Ukrainian)

[35] Datawrapper. Available at: https://www.datawrapper.de. 
Address: Mariia Danyliuk, Marta Dmytryshyn, Ivano-Frankivsk Educational and Scientific Institute of Management of West Ukrainian National University, 32 Dnistrovska Str., Ivano-Frankivsk, 76015, Ukraine.

E-mail: m.danyliuk@wunu.edu.ua, m.dmytryshyn@wunu.edu.ua.

Received: February 19, 2021; revised: March 29, 2021.

Данилюк Марія, Дмитришин Марта. Державний фонд регіонального розвитку України: сучасні реалії, можливості та перспективи. Журнал Прикарпатського національного університету імені Василя Стефаника, 8 (3) (2021), 17-34.

У статті досліджено сучасні реалії функціонування Державного фонду регіонального розвитку, як бюджетної програми у складі Державного бюджету України. Метою дослідження $є$ розкриття ключових особливостей функціонування Фонду в сучасних умовах, оцінка поточного стану фінансового забезпечення проєктів регіонального, виявлення основновних проблем та напрацювання можливих шляхів їх вирішення. У статті обгрунтовано важливість сталого розвитку територій як режиму функціонування регіону, що характеризується гармонійними позитивними змінами в найваждивіших сферах життєдіяльності особистості, суспільства і держави з урахуванням інтересів нинішнього і майбутніх поколінь. Оцінено зміну тенденції розриву між декларованими та затвердженими обсягами фінансування проєктів регіонального розвитку за 2015-2021 роки та окреслено можливі наслідки такого розриву. На карті України відзначено обсяги та кількість проєктів регіонального розвитку в обласному й регіональному вимірі, що були профінансовані в рамках Державного фонду регіонального розвитку України у 2020 році. Підкреслено необхідність рівномірного розподілу проектного фінансування на основі нового зонування та усунення "білих плям" на карті проектів. Досліджено співвідношення кількості проєктів регіонального розвитку у розрізі населених пунктів реалізації у відповідності до їх статусу. Проведено структурний аналіз використання коштів Державного фонду регіонального розвитку України за цільовим призначенням і характером виконаних робіт; розраховано та порівняно середню вартість проєктів регіонального розвитку за категоріями та в цілому. На основі проведеного аналізу виявлено "вузькі місця" функціонування Державного фонду регіонального розвитку України на сучасному етапі та запропоновано шляхи їх вирішення.

Ключові слова: Державний фонд регіонального розвитку, регіональний розвиток, сталий розвиток, проєкти регіонального розвитку, фінансування регіонального розвитку. 